\title{
Sandeel as a link between primary production and higher trophic levels on the Faroe shelf
}

\author{
Kirstin Eliasen ${ }^{1,2, *}$, Jákup Reinert ${ }^{1}$, Eilif Gaard ${ }^{1}$, Bogi Hansen ${ }^{1,2}$, \\ Jan Arge Jacobsen ${ }^{1}$, Peter Grønkjær ${ }^{2}$, Jens Tang Christensen ${ }^{2}$ \\ ${ }^{1}$ Faroe Marine Research Institute, 110 Tórshavn, Faroe Islands \\ ${ }^{2}$ Department of Biological Sciences, Marine Ecology, Aarhus University, 8200 Aarhus N, Denmark
}

\begin{abstract}
A good correlation has previously been established between primary production and production in higher trophic levels in the marine ecosystem on the Faroe shelf, but identification of potential intermediate species has been missing. Sandeel Ammodytes spp. is known to be of great ecological importance in other areas; thus, we investigated the relationship between primary and sandeel production on the Faroe shelf. Juvenile sandeels have been sampled on the annual Faroese 0-group survey in late June to early July with a standardized procedure since 1982. Measurements on primary production, i.e. estimates of accumulated new primary production and chlorophyll a concentration, have been carried out during spring and summer on the Faroe shelf since 1990 and 1997, respectively. We found positive correlations between the primary production and the mean length and abundance of juvenile sandeels on the Faroe shelf in the period investigated. There was also a highly significant relationship between primary production and an index of juvenile sandeel biomass. Two simple models based on starvation mortality and length-dependent predation mortality, respectively, fitted the data well. These findings verify a clear, almost instantaneous, and rather unique link from primary producers to top predators.
\end{abstract}

KEY WORDS: Ammodytes marinus $\cdot$ Larva $\cdot$ Juvenile $\cdot$ Length $\cdot$ Abundance $\cdot$ Biomass index $\cdot$ Chlorophyll a Resale or republication not permitted without written consent of the publisher

\section{INTRODUCTION}

Interannual variation in growth and recruitment of cod and haddock, and in the number of attending guillemots Uria aalge, on the Faroe shelf has been found to correlate with the interannual variations in potential new primary production, i.e. the relative nitrate assimilation in the shelf water ecosystem during the high productive period (Gaard et al. 2002, Steingrund \& Gaard 2005). This implies a near instantaneous transfer of energy from primary production to higher trophic levels of the marine ecosystem on the Faroe shelf, mediated by intermediate species that connect the plankton to non-planktivorous species. This functional role is often held by small, short-lived zooplanktivorous fish species such as capelin Mallotus villosus, sprat Sprattus sprattus or sandeel Ammodytes spp. (Vilhjálmsson 2002, Frederiksen et al. 2006, Østerblom et al. 2006).

The effect of commercial fishery on fish stocks such as cod and haddock makes the bottom-up impact on stock size and productivity considerably harder to detect. However, both Yaragina \& Marshall (2000) and Rose \& O'Driscoll (2002) found the lipid condition index values, an indicator of physical condition of cod Gadus morhua in the Barents Sea and off Newfoundland and Labrador to be positively correlated to the biomass of capelin, another intermediate fish species.

On the Isle of May, southeast Scotland, Frederiksen et al. (2006) found the breeding productivity of 3 seabird species bringing multiple prey items to their 
offspring to positively correlate to the sandeel larval biomass with a 1 yr lag, indicating dependence on 1 yr old fish. The same study (Frederiksen et al. 2006) showed the breeding productivity of a seabird species bringing single prey items to its offspring to be strongly associated with the size of adult sandeels, highlighting the importance of prey quality, as was similarly stated by Wanless et al. (2005).

The lesser sandeel Ammodytes marinus (hereafter sandeel) is known to be an important prey for, e.g., cod, haddock, or seabirds on the Faroe shelf (Rae 1967, Du Buit 1982, Gaard et al. 2002) and might thus function as one of the important trophic nodes in the Faroe shelf ecosystem. However, in order to mediate interannual variability in primary production to higher trophic levels, the abundance, size, availability, or nutritional value (e.g. energy density) of sandeel must be related to primary production through the food available to sandeels, i.e. zooplankton.

Throughout its life, sandeels prey on zooplankton (Reay 1986), and food availability is considered to be a critical factor for growth and survival in the early life stage of sandeel (Arnott \& Ruxton 2002, Frederiksen et al. 2006). Copepod eggs and nauplii are dominant prey items during the early development of most fish larvae, and, thus, the timing and magnitude of copepod production can be essential (McLaren \& Avedaño 1995, Michaud et al. 1996, Gaard \& Steingrund 2001, Voss et al. 2003). Many studies have shown a dependency of copepod reproduction on food availability (e.g. Diel \& Tande 1992, Hirche 1996, Niehoff et al. 1999), predominantly phytoplankton (Irigoien 1998, Meyer-Harms et al. 1999), and seasonal variations in phytoplankton development can thus often be detected in subsequent copepod reproduction and growth (Gaard 1999, Durbin et al. 2003, Devreker et al. 2005). At high latitudes, e.g. on the Faroe shelf, the seasonal variations in primary production are large, and the timing and magnitude of it significantly influence copepod production, species composition, and abundance (Gislason \& Astthorsson 1995, Gaard 1999, Debes et al. 2008a).

Despite its relatively small size $\left(\sim 10000 \mathrm{~km}^{2}\right)$ the Faroe shelf $\left(62^{\circ} 00^{\prime} \mathrm{N}, 06^{\circ} 47^{\prime} \mathrm{W}\right)$ contains a distinct neritic ecosystem surrounded by an oceanic environment. The shelf water is relatively well separated from the open ocean by a persistent front that surrounds the shelf, usually at a bottom depth of between 100 and $130 \mathrm{~m}$ (Fig. 1) (Gaard et al. 1998, Larsen et al. 2002, 2009). Tidal rectification and other effects drive a current system that circles the islands in a clockwise direction (Hansen 1992). Due to strong

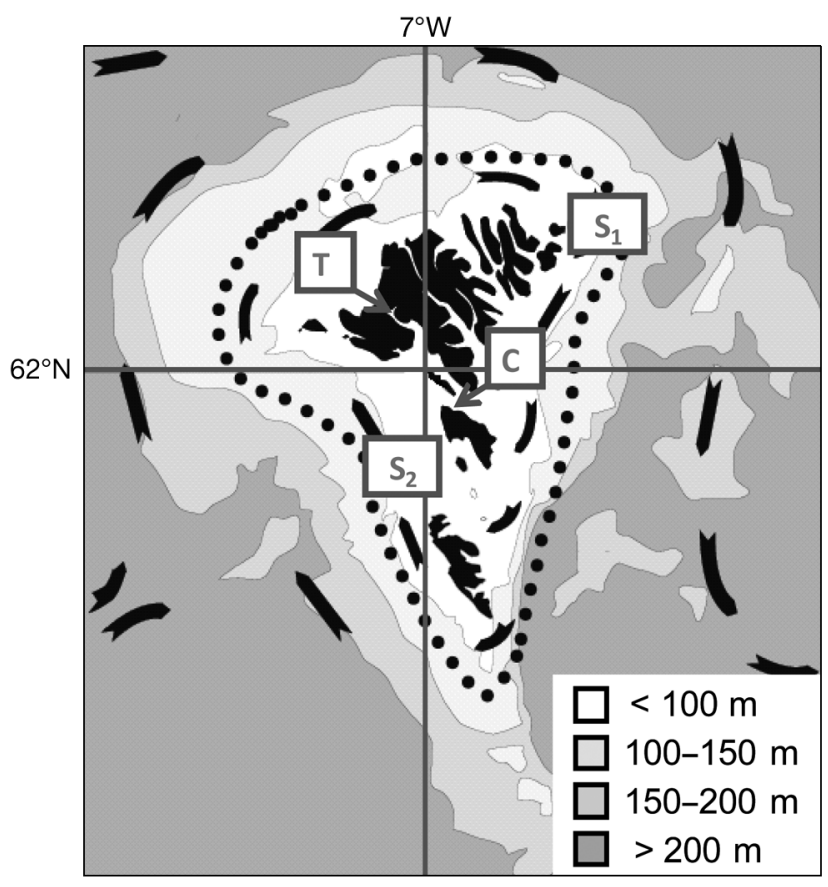

Fig. 1. Topography and main features of the flow field around the Faroes. The dotted line enclosing the light grey area around the shelf indicates the typical position of the tidal front that separates the shelf water from the off-shelf water.

Letters: sampling stations (see 'Materials and methods')

tidal currents, the water column in the shallow parts of the shelf is mixed from surface to bottom throughout the year and no summer stratification occurs (Gaard 1996, Gaard et al. 1998). The average residence time of the shelf water is estimated to be about 2 to $3 \mathrm{mo}$, but it is highly variable and the monthly flushing rates may vary by a factor of 6 (Gaard \& Hansen 2000, Gaard 2003). The timing and intensity of the spring bloom on the Faroe shelf can vary considerably from one year to the next (Gaard et al. 2002, Debes et al. 2008b), and one hypothesis is that these variations are linked to the exchange rate between on- and off-shelf water, where intensive exchange in spring leads to relatively large losses of phytoplankton from the shelf, retarding development of intensive spring blooms (Eliasen et al. 2005, Hansen et al. 2005).

The apparent rapid conversion of primary production to the biomass of higher trophic levels on the Faroe shelf warrants further study. The aim of the present paper is thus to investigate the relationship between primary production and sandeel production on the Faroe shelf by comparing measurements of primary production during the spring bloom with the mean length and abundance of juvenile sandeels as observed during the annual 0-group surveys in late 
June to early July. Such a relationship can be caused by starvation mortality, but it can also be due to length-dependent predation, i.e. if high primary production leads to faster growth rates and hence reduced predation mortality of juvenile sandeels. Therefore, we also address the question of starvation versus predation mortality.

\section{MATERIALS AND METHODS}

\section{Juvenile sandeel data}

Annual 0-group surveys have been conducted on the Faroe shelf in late June to early July since 1974. In 1982 the research vessel was replaced, and the data processing were made more complete. The data from the 2 periods are therefore not comparable, and here we only use the sandeel data from 1982 to 2010 , which covers the whole period with primary production data.

The 0-group survey is primarily designed to obtain information on the year class strength of cod, but other fish species, e.g. sandeels, are caught as well. Further details about the 0-group surveys are given in Jákupstovu \& Reinert (1994). A total of $\sim 70$ trawl stations, evenly distributed at fixed positions at bottom depths of from 45 to 150 m, were occupied each year.

The juvenile sandeels were collected with a capelin trawl $(5 \mathrm{~mm}$ mesh in the cod-end, mouth opening $\sim 8 \mathrm{~m}$ [horizontally] by 4 to $5 \mathrm{~m}$ [vertically]). The trawling depth was 25 to $45 \mathrm{~m}$; the exact depth was chosen based on the recordings of the echosounder. The towing speed was 3 knots, and the duration of each haul was $30 \mathrm{~min}$. In cases of large catches, sub-samples were analysed, and the results were scaled to total catches. Fish were identified to genus, and counted on board. Their total length was measured to the nearest whole millimetre, and the mean total length $(L)$ each year was found by averaging over all individuals caught. The average number of juvenile sandeels caught per station will hereafter either be referred to as abundance or mean number $\left(N_{0}\right)$. Assuming a constant condition factor, an index of the biomass (BI) should be proportional to the number $(N)$ times the length $(L)$ cubed.

Previous identification studies of sandeel larvae, juveniles, and adults, based on the publications of Russel (1976), Reay (1986), and Muus \& Nielsen (1998) and performed by present first author, have indicated that Ammodytes marinus is the absolutely dominant sandeel species on the Faroe shelf.

\section{Temperature}

Data on temperature dating back to February 1992 were acquired from Stn T (Fig. 1). The station was selected to fulfil the requirements that the measurements be taken in well-mixed water, open to the ocean, and far from river runoff. It thus represents the whole water column, and can be used as sea surface temperature. In the present study, only the monthly mean temperatures for February, March, April, May, and June were applied.

\section{Primary production index}

A measure of the accumulated new primary production (PP-index) in the Faroe shelf water ecosystem during spring and summer from 1990 to 2010 was calculated based on the reduction in nitrate concentration from winter levels until a fixed date (June 26 each year) at Stns $S_{1}$ and $S_{2}$ (Fig. 1) plus estimated net influx of nitrate from the surrounding off-shelf water during the same time period (Gaard 2003):

$\mathrm{PP}$-index $=$ nitrate decrease + nitrate net inflow from winter until June 26. June 26 is close to the time when the nitrate concentration on the Faroe shelf in most years is at a minimum (Debes et al. 2008b). The inflow of nitrate is calculated as:

Nitrate net inflow $=$ renewal rate of shelf water $\times$

$$
\left(\left[\mathrm{NO}_{3}{ }^{-}\right]_{\text {off-shelf }}-\left[\mathrm{NO}_{3}^{-}\right]_{\text {on-shelf }}\right)
$$

where $\left[\mathrm{NO}_{3}{ }^{-}\right]_{\text {offshelf }}$ and $\left[\mathrm{NO}_{3}{ }^{-}\right]_{\text {on-shelf }}$ are the nitrate concentrations in the surrounding off-shelf and onshelf water, respectively. The average renewal rate of the on-shelf water is estimated to be about $1 / 75 \mathrm{~d}^{-1}$ (Gaard 2003). The renewal rate is mainly based on the nitrate reduction on-shelf, but is corrected for horizontal nitrate import to the shelf as described by Steingrund \& Gaard (2005). For short timescales, an assumption of constant horizontal exchange rates is not very realistic (Gaard \& Hansen 2000), but, in the timescale used here $\left(2 \frac{1}{2} \mathrm{mo}\right)$, the correction is relatively small, and varying the horizontal exchange rate within realistic bounds only causes small changes in the index (Hansen et al. 2005).

Samples for measurement of nitrate were collected at stations that were evenly distributed on the shelf and slope in late June 1990 to 2010. In 1990, samples were stored in a refrigerator and analysed a few days after sampling. From 1991 to 1994, samples were frozen immediately after collection and analysed ashore. The sample storage prior to measurements 
did not seem to affect the results of the nutrient analysis. Since 1995, samples have been analysed onboard the same day or the day after collection. Nitrate + nitrite were measured on an auto-analyser according to Grasshoff et al. (1983).

\section{Chlorophyll a data}

For measurement of chlorophyll a (chl a ), frequent sampling was carried out at a land-based station (Stn $C_{i}$ Fig. 1). This station pumps large amounts of seawater (about $15 \mathrm{t} \mathrm{min}^{-1}$ ) from $18 \mathrm{~m}$ depth at a location on the central shelf, where the water column is always well mixed from surface to bottom. Since 1997, the samples have been collected on a weekly basis from April until September, but here we only analyse the period from April to late June. Chl a was measured spectrophotometrically according to Parsons et al. (1984), and calculations were made according to Jeffrey \& Humphrey (1975). When comparing interannual variability of chl a concentrations in this time series, daily concentrations were calculated by linear interpolation between the weekly measurements. the period February up to and including June, the yr 2003 had the highest $\left(7.7^{\circ} \mathrm{C}\right)$ and the yr 1995 had the lowest $\left(6.2^{\circ} \mathrm{C}\right)$ mean temperature. Separately, the months showed little variation interannually. No significant correlation between temperature and juvenile sandeel length or abundance was found.

The PP-index varied by a factor of 5.6 in the period from 1990 to 2010, and the mean daily chl a concentration varied by a factor of 6.4 in the period from 1997 to 2010 (Fig. 4). The 2 primary production parameters peaked simultaneously in 2000/2001, 2004, and 2009. In the period prior to the chl a measurements the PP-index had a single peak in 1995. The correlation between the 2 time series was high $\left(\mathrm{R}^{2}=\right.$ 0.89, $\mathrm{p}=0.001$ ).

Both the mean length and number of juvenile sandeels were positively correlated to the PP-index (Table 1), but the correlations were not significant at the $5 \%$ level. Similarly, mean length and number were positively correlated to chl a concentration (Table 1), but only the correlation between the chl a concentration and mean juvenile sandeel length was significant (Table 1, Fig. 5). The juvenile sandeel biomass index was correlated to both the PP-index $\left(\mathrm{R}^{2}=\right.$ $0.43, \mathrm{p}=0.024)$ and chl a concentration $\left(\mathrm{R}^{2}=0.73, \mathrm{p}=\right.$ 0.010) (Figs. $6 \&$ 7).

\section{Statistical significance}

The statistical significance of the squared correlation coefficients $\left(\mathrm{R}^{2}\right)$ presented in the present paper has been corrected for serial correlation as suggested by Pyper \& Peterman (1998).

\section{DISCUSSION}

Here we have shown that length and abundance of juvenile sandeels, especially when expressed as a biomass index, are positively correlated to the primary production on the Faroe shelf. In a similar way,

\section{RESULTS}

The number (mean $\pm \mathrm{SE}$ ) of juvenile sandeels varied by a factor of 1650, 1989 being the year with the lowest $(5 \pm 2)$ and 2008 being the year with the highest $(8052 \pm 2111)$ number. The juvenile sandeel length (mean $\pm \mathrm{SE}$; mm) varied by a factor of 3.3, 1989 having the smallest (19.9 \pm 0.8$)$ and 1985 having the largest specimens (65.8 \pm 1.1) (Fig. 2). There was a significant positive correlation between mean length and number in the period from 1982 to $2010\left(\mathrm{R}^{2}=\right.$ $0.19, \mathrm{p}=0.017$ ).

The monthly mean temperature varied interannually during the period investigated (1992 to 2010) (Fig. 3). For

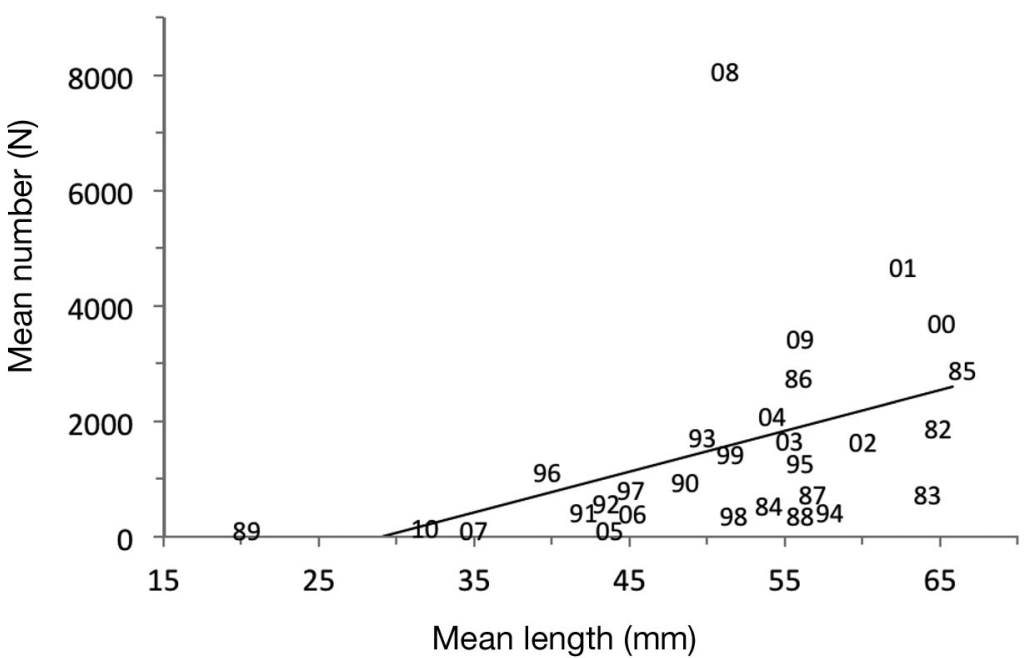

Fig. 2. Ammodytes marinus. Regression between the mean length (mm) and mean number $(N)$ of juveniles caught per station on the Faroe shelf in the period from 1982 to $2010\left(R^{2}=0.19, p=0.017\right)$. Numbers = year of sampling 


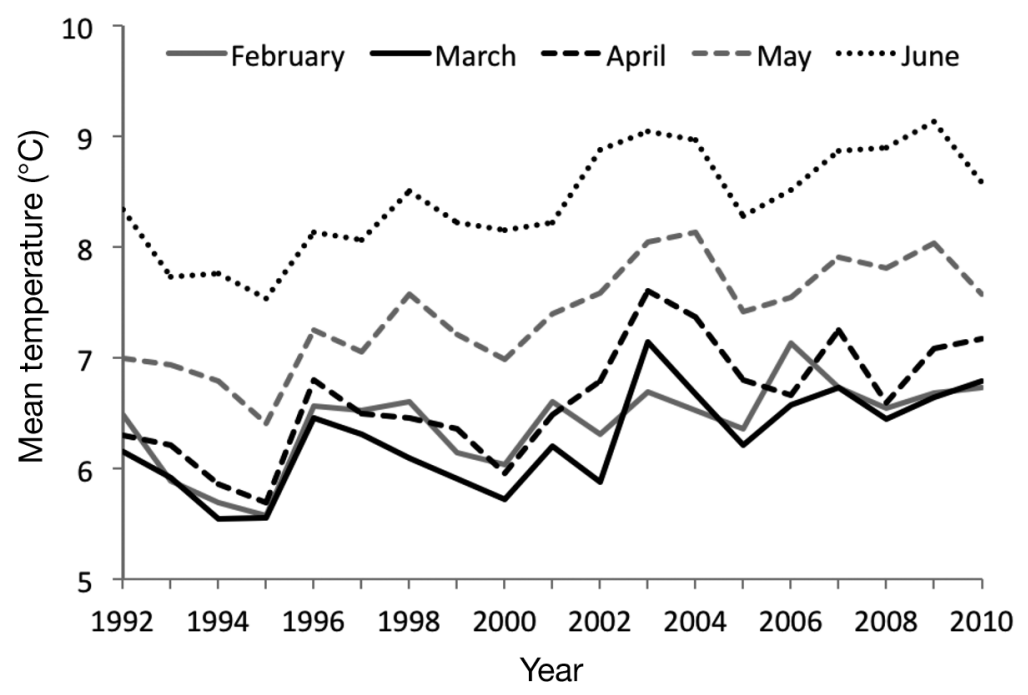

Fig. 3. Interannual variations in mean monthly temperature $\left(\mathrm{C}^{\circ}\right)$ on the Faroe shelf in the months February to June from 1992 to 2010

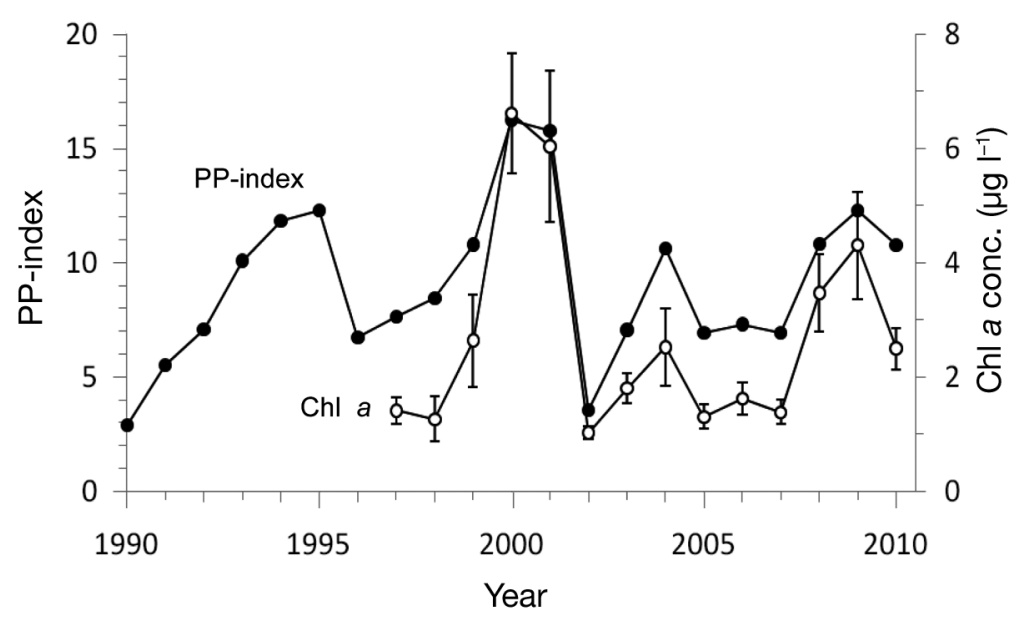

Fig. 4. Interannual variations in the primary production (PP)-index in the period from 1990 to 2010 and in the daily chlorophyll a (chl a) concentration (means $\pm \mathrm{SE}$ ) in the period from 1997 to 2010 on the Faroe shelf $\left(\mathrm{R}^{2}=\right.$ $0.89, \mathrm{p}=0.001)$

Table 1. Ammodytes marinus. Squared correlation $\left(\mathrm{R}^{2}\right)$, significance $(\mathrm{p})$, and number $(N)$ of the primary production (PP) and juvenile sandeel parameters. Chl a: chlorophyll a

\begin{tabular}{|c|c|c|c|c|c|c|}
\hline & & \multirow{2}{*}{$\begin{array}{c}\text { PP-index } \\
p\end{array}$} & \multirow{2}{*}{$\bar{N}$} & \multicolumn{3}{|c|}{ Chl a concentration } \\
\hline & $\mathrm{R}^{2}$ & & & $\mathrm{R}^{2}$ & $\mathrm{p}$ & $N$ \\
\hline Mean length & 0.24 & 0.06 & 21 & 0.34 & 0.04 & 14 \\
\hline Mean number & 0.26 & 0.07 & 21 & 0.43 & 0.07 & 14 \\
\hline Biomass & 0.43 & 0.02 & 21 & 0.73 & 0.01 & 14 \\
\hline
\end{tabular}

Steingrund \& Gaard (2005) found positive and significant relationships between the PP-index and cod recruitment on the Faroe shelf. The authors argued that this clear signal most likely was due to a cod diet consisting of food items younger than $1 \mathrm{yr}$, for example 0-group sandeels. Feeding on older and longer living prey, such as crustaceans, which post-settlement cod on the Faroe shelf prey on in the absence of sandeels (Rae 1967, Du Buit 1982), would not likely be able to transmit the phytoplankton signal this quickly. The almost instantaneous response of higher fish species, e.g. cod, to the primary production on the Faroe shelf, therefore, indicates a fast-growing zooplanktivorous species as a transmitter, and, based on stomach analysis of higher fish species (Rae 1967, Du Buit 1982), an obvious candidate would be sandeel.

In other areas, good relationships have been shown between primary production and sandeel hatch date (Hart 1974, Wright \& Bailey 1996), and the recruitment of another sandeel species (Ammodytes americanus) has also been observed to correlate positively with primary production (Monteleone \& Peterson 1986), although we know of no other study in which a significant positive correlation has been established between mean daily chl $a$ concentration and juvenile sandeel length. None of the other 3 correlations presented here, i.e. between the mean daily chl a concentration and mean juvenile sandeel number, and between the PP-index and mean juvenile sandeel number and length (see also Table 1), were significant. However, their corrected $\mathrm{p}$-values were all $<0.08$.

Since juvenile sandeels only prey directly upon phytoplankton to a limited extent, the primary production estimates presented here do not qualify as a direct measure of the actual food availability, but rather as an indicator of it. However, several studies have shown that the seasonal devel- 


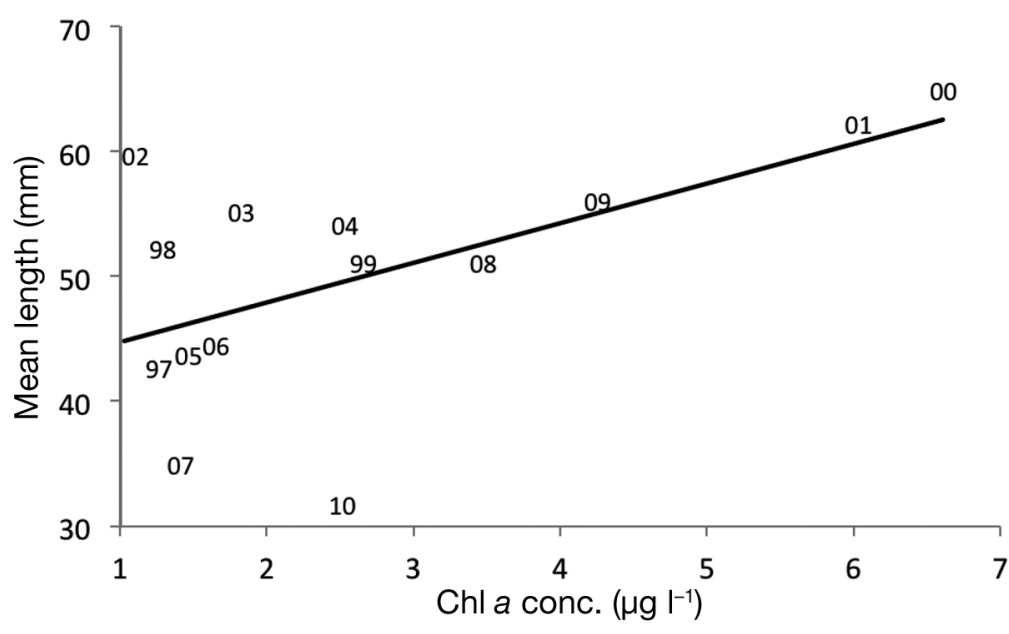

Fig. 5. Ammodytes marinus. Regression between the chlorophyll a (chl a) concentration $\left(\mu \mathrm{g} \mathrm{l}^{-1}\right)$ and mean length $(\mathrm{mm})$ of juveniles on the Faroe shelf in the period from 1997 to $2010\left(R^{2}=0.34, p 0.04\right)$. Numbers = year of sampling

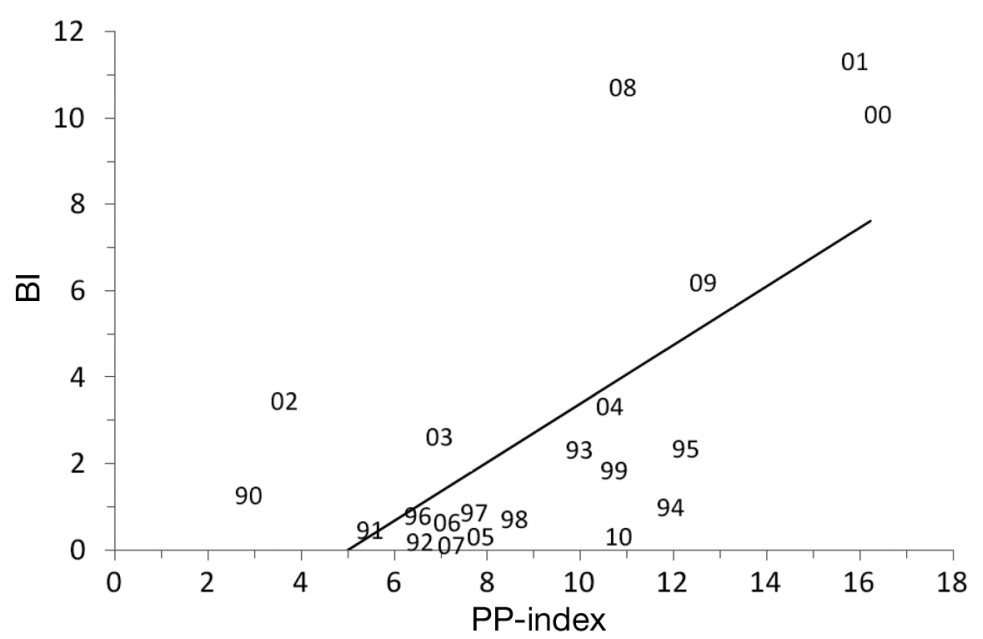

Fig. 6. Ammodytes marinus. Regression between the primary production (PP)-index and the biomass index of juveniles (BI) on the Faroe shelf in the period from 1990 to $2010\left(R^{2}=0.43, p=0.024\right)$. Numbers = year of sampling

availability. The correlations observed between the mean juvenile sandeel length and primary production on the Faroe shelf, thus seem reasonable. Additionally, our findings on the strong correlation between primary production and the biomass index are consistent with the findings of Frederiksen et al. (2006), who observed the biomass of sandeel larvae sampled May 1 to be positively correlated to the plankton abundance during their period of growth.

The 2 time series representing primary production (the PP-index and the interpolated mean daily chl a concentration) were based on measurements of 2 totally different variables, i.e. nitrate and chl a concentrations. Their high correlation $\left(\mathrm{R}^{2}=0.89, \mathrm{p}=0.001\right)$ is therefore an indicator of high data quality. On the other hand, the sandeel data were collected on cruises primarily designed to obtain information on 0-group cod, which may influence data quality in several ways. Firstly, the juvenile sandeel is long and slender, and has a tendency to get entangled in the mesh on its way back into the cod end of the trawl. Therefore, the abundance values most likely will be underestimated, while the length distributions might be biased due to size selection of the types of mesh. Secondly, the timing of the 0-group surveys is most likely postmetamorphosis for sandeels, and the juvenile sandeel might thus have initiated its daily vertical migration in the water column or perhaps even have settled-

opment in primary production is typically followed by a subsequent and similar development in the secondary producers, e.g. zooplankton (Niehoff et al. 1999), and this is also the case on the Faroe shelf (Gaard 1999, Debes \& Eliasen 2006).

A multitude of studies have documented the effect of food on the condition factor and weight growth of various fish species at different life stages. The effect of food on length growth has received much less attention, but it is well known that growth may be arrested during periods of low food availability (Blaxter 1969, Checkley 1984). We know of no study that links length growth of early life stage sandeel to food, but Folkvord et al. (2009) showed that herring larvae with high food availability could grow twice as fast in length compared to herring larvae with low food probably leading to decreased availability to the trawl. All this adds to the uncertainties in the sandeel data, both regarding length and number. However, the validity of the time series is strengthened by the fact that the data range over a period of $29 \mathrm{yr}$ during which time the sampling method has remained the same.

The sandeel larva is planktonic and bound to drift with the currents of its surroundings, and if the surrounding water is headed away from suitable habitat, e.g. off-shelf, it might be lost (Wright \& Bailey 1996). Drift off-shelf might thus be a source of larval mortality and induce a spurious correlation between primary production and sandeel abundance without requiring a causal mechanism between them, since the exchange between on-shelf and off-shelf waters 


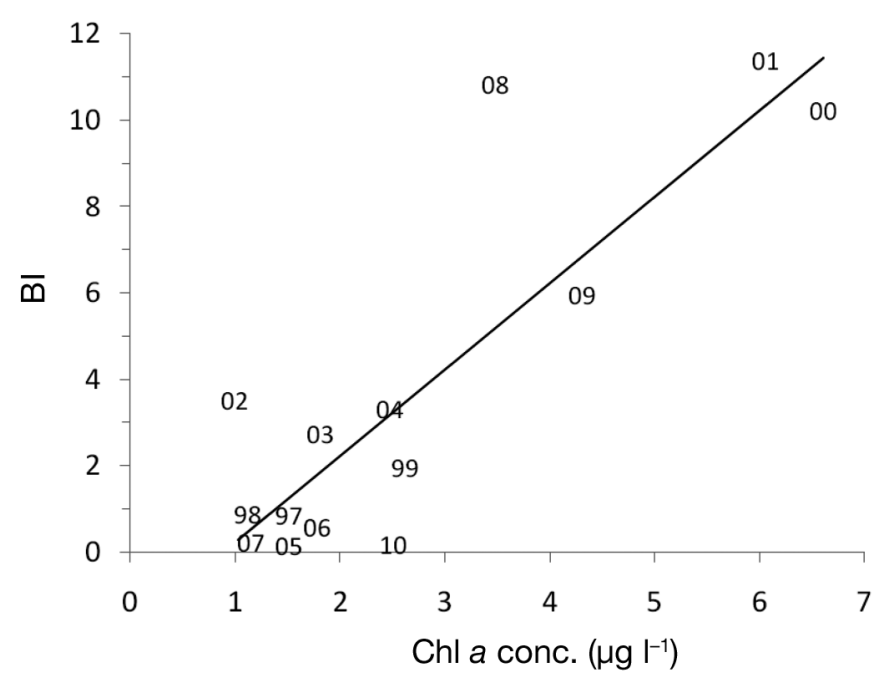

Fig. 7. Ammodytes marinus. Regression between the chlorophyll a ( $\mathrm{chl}$ a) concentration $\left(\mu \mathrm{g} \mathrm{l}^{-1}\right)$ and the biomass index of juveniles (BI) on the Faroe shelf in the period from 1997 to $2010\left(R^{2}=0.73, p=0.010\right)$. Numbers = year of sampling

has also been suggested to control the spring bloom (Eliasen et al. 2005, Hansen et al. 2005). If this mechanism is supported, years with strong off-shelf exchange would have low primary production (through phytoplankton export) and export a relatively large number of sandeels, and vice versa. Variations in the exchange rate are, however, more than an order of magnitude lower than the variations in 0-group sandeel abundance (Gaard \&Hansen, 2000, Hansen et al. 2005). Finally, it would be hard to explain the observed positive correlation between mean juvenile sandeel length and primary production on the Faroe shelf by larval drift off-shelf.

\section{The effect of food availability on juvenile sandeel mortality}

Food availability, predation and temperature are generally considered to be the most influential factors affecting fish larval survival. The results indicate that temperature most likely does not have any significant influence on the interannual variations observed in the mean length and abundance of juvenile sandeels on the Faroe shelf.

Arnott \& Ruxton (2002) found sandeel recruitment in the North Sea to be under the influence of demographic effects, i.e. density-dependent processes such as cannibalism and competition for seabed space and food, especially performed by 1 yr old cospecimens. Van Deurs et al. (2009) further substantiated this by illustrating how the otherwise positive correlation observed between spawning stock biomass and sandeel recruitment $\left(N_{0}\right)$ vanished in years with large stocks of 1 yr old sandeels. However, we have not been able to detect correlations of this kind. Nonetheless, our assessments of the sandeel stock sizes, $N_{1}$ and $N_{\text {spawning, }}$ were inferred from the 0-group data according to Cook \& Reeves (1993) and Cook (2004) and might thus be of poor quality. However, Rae (1967) found that the food of Faroe shelf cod in the period from 1949 to 1962 mainly consisted of sandeel, but, in recent years (1997 to 2006), sandeel has only ranked third in the cod diet (Steingrund 2009). If this change in the species composition of cod diet indicates that the sandeel stock was much larger in the mid-twentieth century compared to recent years, the sandeel stock in recent years most likely has not been at a maximum carrying capacity; hence, demographic effects on sandeel recruitment should be much less likely.

As part of the explanation of the variability in fish recruitment, Cushing (1974) suggested a hypothesis on the matching and mismatching in the time of larval production and the production of their food. The onset of the primary production bloom on the Faroe shelf has interannually been observed to vary a great deal in time (Gaard et al. 1998). However, we have not been able to detect a significant relationship between the mean number of juvenile sandeel on the Faroe shelf and the onset of the spring bloom, at least not when the date of the onset of the spring bloom is defined according to Wright \& Bailey (1996) as being the date when the chl a concentration first reaches levels $>1.0 \mathrm{mg} \mathrm{m}^{-3}\left(\mathrm{R}^{2}=0.21, \mathrm{p}=0.110\right)$, nor when it is defined according to Sharples et al. (2006) as the first day of 5 consecutive days with chl a concentration $>2.0 \mathrm{mg} \mathrm{m}^{-3}\left(\mathrm{R}^{2}=0.383, \mathrm{p}=0.087\right)$.

After metamorphosis, when juvenile sandeels adapt the burrowing behaviour characteristic of adults, predation mortality decreases considerably (Wright et al. 2000). Metamorphosis is often correlated to length, i.e. higher growth rates lead to shorter larval phases (Benoît et al. 2000), and, thereby, also to an earlier size-related exclusion of predators (Van Deurs et al. 2009). If a great mean length in late June to early July symbolizes a preceding high growth rate, and, thereby, a short larval phase, our finding on high abundances in years with large mean lengths seems reasonable.

The effect of food availability on sandeel recruitment, thus, could be through increased mortality in periods of both starvation and/or high predation pressure. In Appendix 1, Eqs. (A1) to (A4), we present a simple model for starvation mortality, which implies a 
relationship between the mean number of sandeel caught during the 0-group survey, $N_{T}$, and their mean length, $L_{T}$ :

$$
\ln \left(N_{T}\right)=a-b \cdot\left(\frac{1}{L_{T}}\right)
$$

where $a$ and $b$ can be considered constants. To explore the validity of this model, we have plotted $\ln \left(N_{T}\right)$ against $1 / L_{T}$ (Fig. 8), and Eq. (1) explains $72 \%$ of the variance in $\ln \left(N_{T}\right)$. This result is encouraging compared to the original plot presented (Fig. 2), which only explained $19 \%$. However, exactly the same kind of functional relationship between $N_{T}$ and $L_{T}$ can be derived from a model, Eq. (A5), in which mortality is only by predation, but where the predation mortality decreases with prey length, as is commonly argued (Leggett \& DeBlois 1994), at the same time as length growth increases with food availability.

Overall, regarding the Faroe shelf, we can conclude that juvenile sandeel length and abundance are positively correlated to the primary production in the area, and that this most likely contributes to the previously recognised clear and close signal between primary production and cod production on the Faroe shelf (Steingrund \& Gaard 2005).

We believe that this clear link between primary producers and top predators is a rather unique occurrence in the literature, and, by documenting the role of sandeel in this cascade, we have strengthened the evidence for this link. That this link is so clear on the Faroe shelf, compared to in other areas, may perhaps be due to a simpler ecosystem, but it could also be due to its homogeneity, both regarding environmental factors and species composition.

The results presented here do not, however, settle the question on whether the interannual variations in the abundance of juvenile sandeel observed on the Faroe shelf in the period from 1982 to 2010 are caused by starvation, predation, or a combination of both.

Acknowledgements. We thank the crew on the Faroese research vessel RV 'Magnus Heinason' for assistance in the field. Thanks to the Fisheries Research Found of the Faroe Islands and the Danish Agency for Science, Technology and Innovation for funding this research.

\section{LITERATURE CITED}

Arnott SA, Ruxton GD (2002) Sandeel recruitment in the North Sea: demographic, climatic and trophic effects. Mar Ecol Prog Ser 238:199-210
Benoît HP, Pepin P, Brown JA (2000) Patterns of metamorphic age and length in marine fishes, from individuals to taxa. Can J Fish Aquat Sci 57:856-869

Blaxter JHS (1969) Development: eggs and larvae. In: Hoar WS, Randall DJ (eds) Fish physiology, Vol 8. Academic Press, New York, NY, p 177-252

Checkley DM (1984) Relation of growth to ingestion for larvae of Atlantic herring Clupea harengus and other fish. Mar Ecol Prog Ser 18:215-224

> Cook RM (2004) Estimation of the age-specific rate of natural mortality for Shetland sandeels. ICES J Mar Sci 61: 159-164

Cook RM, Reeves SA (1993) Assessment of North Sea industrial fish stocks with incomplete catch-at-age data. ICES J Mar Sci 50:425-434

Cushing DH (1974) The possible density-dependence of larval mortality and adult mortality in fishes. In: Blaxter JHS (ed) The early life history of fish. Springer, Heidelberg, p 103-111

Debes HH, Eliasen K (2006) Seasonal abundance, reproduction and development of four key copepod species on the Faroe Shelf. Mar Biol Res 2:249-259

Debes H, Eliasen K, Gaard E (2008a) Seasonal variability in copepod ingestion and egg production on the Faroe shelf. Hydrobiologia 600:247-265

> Debes HH, Gaard E, Hansen B (2008b) Primary production on the Faroe shelf: temporal variability and environmental influences. J Mar Syst 74:686-697

> Devreker D, Souissi S, Seuront L (2005) Effects of chlorophyll concentrations and temperature variation on the reproduction and survival of Temora longicornis (Copepoda, Calanoida) in the eastern English Channel. J Exp Mar Biol Ecol 318:145-162

> Diel S, Tande K (1992) Does the spawning of Calanus finmarchicus in high latitudes follow a reproducible pattern? Mar Biol 113:21-31

Du Buit MH (1982) Essai sur la predation de la morue (Gadus morhua (L.)), l'églefin (Melanogrammus aeglefinus (L.)) 
et du lieu noir (Pollachius virens (L.)) aux Faeroe. Cybium 6:3-13

> Durbin EG, Campbell RG, Casas MC, Ohman MD, Niehoff B, Runge J, Wagner M (2003) Interannual variation in phytoplankton blooms and zooplankton productivity and abundance in the Gulf of Maine during winter. Mar Ecol Prog Ser 254:81-100

> Eliasen SK, Gaard E, Hansen B, Larsen KMH (2005) A ‘horizontal Sverdrup mechanism' may control the spring bloom around small oceanic islands and over banks. J Mar Syst 56:352-362

Folkvord A, Høie H, Johannessen A, Solbakken T (2009) Effects of prey concentration, light regime, and parental origin on growth and survival of herring larvae under controlled experimental conditions. ICES J Mar Sci 66: 1702-1709

- Frederiksen M, Edwards M, Richardson AJ, Halliday NC, Wanless S (2006) From plankton to top predators: bottom-up control of a marine food web across four trophic levels. J Anim Ecol 75:1259-1268 Medline

Gaard E (1996) Phytoplankton community structure on the Faroe shelf. Fróðskaparrit 44:96-106

> Gaard E (1999) The zooplankton community structure in relation to its biological and physical environment on the Faroe shelf, 1989-1997. J Plankton Res 21:1133-1152

Gaard E (2003) Plankton variability on the Faroe shelf during the 1990s. ICES Mar Sci Symp 219:182-189

> Gaard E, Hansen B (2000) Variations in the advection of Calanus finmarchicus onto the Faroese shelf. ICES J Mar Sci 57:1612-1618

Gaard E, Steingrund P (2001) Reproduction of Faroe plateau cod: spawning grounds, egg advection and larval feeding. Fróðskaparrit 48:87-103

Gaard E, Hansen B, Heinesen SP (1998) Phytoplankton variability on the Faroe shelf. ICES J Mar Sci 55:688-696

Gaard E, Hansen B, Olsen B, Reinert J (2002) Ecological feature and recent trends in the physical environment, plankton, fish stocks, and seabirds in the Faroe shelf ecosystem. In: Sherman K, Skjoldal HR (eds) Large marine ecosystems in the North Atlantic. Elsevier, Amsterdam, p 245-265

Gislason A, Astthorsson OS (1995) Seasonal cycle of zooplankton southwest of Iceland. J Plankton Res 17: 1959-1976

Grasshoff K, Erhardt M, Kremling K (eds) (1983) Methods for seawater analysis, 2nd revised and extended edition. Verlag Chemie, Weinheim

Hansen B (1992) Residual and tidal currents on the Faroe plateau. ICES CM 1992/C:12 18p

> Hansen B, Eliasen SK, Gaard E, Larsen KMH (2005) Climatic effects on plankton and productivity on the Faroe shelf. ICES J Mar Sci 62:1224-1232

Hart PJB (1974) The distribution and long term changes in abundance of larval Ammodytes marinus (Raitt) in the North Sea. In: Blaxter JHS (ed) The early life history of fish. Springer, Heidelberg, p 171-182

Hirche HJ (1996) The reproductive biology of the marine copepod, Calanus finmarchicus - a review. Ophelia 44: $111-128$

Irigoien X (1998) Gut clearance rate constants, temperature and initial gut contents: a review. J Plankton Res 20: 997-1003

Jákupstovu SH, Reinert J (1994) Fluctuations in the Faroe plateau cod stock. Mar Sci Symp 198:194-211

Jeffrey SW, Humphrey GF (1975) New spectrophotometric equations for determining chlorophyll $a, b, c_{1}$ and $c_{2}$ in higher plants and natural phytoplankton. Biochem Physiol Pflanz 167:191-194

Larsen KMH, Hansen B, Svendsen H, Simonsen K (2002) The front on the Faroe shelf. ICES CM 2002/P:10

Larsen KMH, Hansen B, Svendsen H (2009) The Faroe shelf front: properties and exchange. J Mar Syst 78:9-17

- Leggett WC, DeBlois E (1994) Recruitment in marine fishes: Is it regulated by starvation and predation in the egg and larval stages? Neth J Sea Res 32:119-134

McLaren IA, Avedaño P (1995) Prey field and diet of larval cod on Western Bank, Scotian shelf. Can J Fish Aquat Sci 52:448-463

Meyer-Harms B, Irigoien X, Head R, Harris R (1999) Selective feeding on natural phytoplankton by Calanus finmarchicus before, during, and after the 1997 spring bloom in the Norwegian Sea. Limnol Oceanogr 44:154-165

> Michaud J, Fortier L, Rowe P, Ramseier R (1996) Feeding success and survivorship of Arctic cod larvae, Boreogadus saida, in the Northeast Water Polynya (Greenland Sea). Fish Oceanogr 5:120-135

> Monteleone DM, Peterson WT (1986) Feeding ecology of American sand lance Ammodytes americanus larvae from Long Island Sound. Mar Ecol Prog Ser 30:133-143

Muus BJ, Nielsen JG (eds) (1998) Tobiser. In: Havfisk og fiskeri. Gads forlag, Copenhagen, p 213-216

> Niehoff B, Klenke U, Hirche HJ, Irigoien X, Head R, Harris $R$ (1999) A high frequency time series at Weathership $M$, Norwegian Sea, during the 1997 spring bloom: the reproductive biology of Calanus finmarchicus. Mar Ecol Prog Ser 176:81-92

Østerblom H, Casini M, Olsson O, Bignert A (2006) Fish, seabirds and trophic cascades in the Baltic Sea. Mar Ecol Prog Ser 323:233-238

Parsons T, Maita Y, Lalli C (1984) A manual of chemical and biological methods for seawater analysis. Pergamon Press, Oxford

- Pyper BJ, Peterman RM (1998) Comparison of methods to account for autocorrelation in correlation analyses of fsh data. Can J Fish Aquat Sci 55:2127-2140

Rae BB (1967) The food of cod and haddock of Faroese grounds. Mar Res 6:1-23

Reay PJ (1986). Ammodytidae. In: Whitehead PJP, Baucjot ML, Hurreau JC, Tortones J (eds) Fishes of the northeastern Atlantic and the Mediterranean. Chauser Press, London, p 945-950

- Rose GA, O'Driscoll RL (2002) Capelin are good for cod: Can the northern stock rebuild without them? ICES J Mar Sci 59:1018-1026

Russell F (1976) The eggs and planktonic stages of British marine fishes. Academic Press, London, p 232-236

Sharples J, Ross ON, Scott BE, Greenstreet SPR, Fraser H (2006) Inter-annual variability in the timing of stratification and the spring bloom in the north-western North Sea. Cont Shelf Res 26:733-751

Steingrund P (2009) The near-collapse of the Faroe plateau cod (Gadus morhua L.) stock in the 1990s: the effect of food availability on spatial distribution, recruitment, natural production and fishery. PhD thesis, University of Bergen, Bergen

> Steingrund P, Gaard E (2005) Relationship between phytoplankton production and cod production on the Faroe Shelf. ICES J Mar Sci 62:163-176

> Van Deurs M, Hal RV, Tomczak MT, Jónasdóttir SH, Dolmer P (2009) Recruitment of lesser sandeel Ammodytes mari- 
nus in relation to density dependence and zooplankton composition. Mar Ecol Prog Ser 381:249-258

Vilhjálmsson H (2002) Capelin (Mallotus villosus) in the Iceland-East Greenland-Jan Mayen ecosystem. ICES J Mar Sci 59:870-883

Voss R, Koester FW, Dickmann M (2003) Comparing the feeding habits of co-occurring sprat (Sprattus sprattus) and cod (Gadus morhua) larvae in the Bornholm Basin, Baltic Sea. Fish Res 63:97-111

Wanless S, Harris MP, Redman P, Speakman JR (2005) Low energy values of fish as a probable cause of a major seabird breeding failure in the North Sea. Mar Ecol Prog
Ser 294:1-8

> Wright PJ, Bailey MC (1996) Timing of hatching in Ammodytes marinus from Shetland waters and its significance to early growth and survivorship. Mar Biol 126: 143-152

Wright PJ, Jensen H, Tuck I (2000) The influence of sediment type on the distribution of the lesser sandeel, Ammodytes marinus. J Sea Res 44:243-256

> Yaragina NA, Marshall CT (2000) Trophic influences on interannual and seasonal variation in the liver condition index of northeast cod (Gadus morhua). ICES J Mar Sci $57: 42-55$

\section{APPENDIX 1}

Consider a cohort of sandeel Ammodytes marinus from the time of hatching in February/March $(t=0)$ to the time of the 0 -group survey in late June $(t=T)$. If $N(t)$ is the number of individuals as a function of time, $t$, we expect:

$$
\frac{d N}{d t}=-m \cdot N \Rightarrow \frac{d}{d t}(\ln (N))=-m \Rightarrow \ln \left(\frac{N_{T}}{N_{0}}\right)=-\int_{0}^{T} m \cdot d t
$$

where the mortality, $m$, may depend on various factors. $N_{T}$ is the number of individuals remaining at time $T$, and $N_{0}$ is the initial number. To relate the model to our observations, we assume that the number of juveniles caught during the 0 -group survey each year is proportional to and can be represented by $N_{T}$. During the same period, the individual length $L(t)$ increases, and, for simplicity, we assume the length development to be the same for all individuals and to be linear with time:

$$
L=\gamma \cdot t
$$

where the growth factor, $\gamma$, in this model is assumed to be constant through the spring until ultimo June each year, but to vary from one year to another due to different food conditions. The length at the time of the 0-group survey is then $L_{T}=$ $\gamma \cdot T$ and we interpret this parameter as the mean length measured during the survey each year (Fig. 2). We now consider 2 separate cases:

\section{Case 1. Mortality dominated by starvation}

Assume that the mortality, $m$, each year has a fixed temporal variation $m_{0}(t)$, which is modulated by the inter-annual variation of food availability through an inverse dependence on the growth factor, $\gamma$, in Eq. (A2):

$$
m(t)=\frac{m_{0}(t)}{\gamma} \Rightarrow \ln \left(\frac{N_{T}}{N_{0}}\right)=-\frac{1}{\gamma} \cdot \int_{0}^{T} m_{0}(t) d t=-\frac{T}{L_{T}} \cdot \int_{0}^{T} m_{0}(t) d t
$$

By the assumptions, the last integral in Eq. (A3) is constant, and this case, therefore, implies a general relationship between $N_{T}$ and $L_{T}$ :

$$
\ln \left(N_{T}\right)=a-b \cdot\left(\frac{1}{L_{T}}\right)
$$

where $a$ and $b$ can be considered constants if the initial number, $N_{0}$, varies much less than $N_{T}$

\section{Case 2. Mortality dominated by length-dependent predation}

Assume that the mortality depends only on length $m=m(L)$. Eq. (A1) then becomes:

$$
\ln \left(\frac{N_{T}}{N_{0}}\right)=-\int_{0}^{T} m(L) d t=-\frac{1}{\gamma} \cdot \int_{0}^{L_{T}} m(L) d L=-\frac{T}{L_{T}} \cdot \int_{0}^{L_{T}} m(L) d L
$$

In nature, we expect mortality to decrease with length (Van Deurs et al. 2009), and, for sandeel, we expect a strong decrease after metamorphosis. If the decrease in mortality from time 0 to $T$ is sufficiently strong, the last integral in Eq. (A3) will be almost constant — this implies that this case leads to exactly the same general relationship, Eq. (A4), as Case 1. 